Research Article

\title{
In Vitro Evaluation of Bacterial Adhesion and Bacterial Viability of Streptococcus mutans, Streptococcus sanguinis, and Porphyromonas gingivalis on the Abutment Surface of Titanium and Zirconium Dental Implants
}

\author{
Ana Stefany Meza-Siccha, ${ }^{1}$ Miguel Angel Aguilar-Luis $\mathbb{D}^{2,3}$ Wilmer Silva-Caso $\mathbb{D}^{2,3}$ \\ Fernando Mazulis, ${ }^{2}$ Carolina Barragan-Salazar, ${ }^{1}$ and Juana del Valle-Mendoza $\mathbb{D}^{2,3}$ \\ ${ }^{1}$ School of Dentistry, Faculty of Health Sciences, Universidad Peruana de Ciencias Aplicadas, Lima, Peru \\ ${ }^{2}$ School of Medicine, Research and Innovation Center of the Health Sciences Faculty, Universidad Peruana de Ciencias Aplicadas, \\ Lima, Peru \\ ${ }^{3}$ Laboratorio de Biología Molecular, Instituto de Investigación Nutricional, Lima, Peru
}

Correspondence should be addressed to Juana del Valle-Mendoza; joana.del.valle@gmail.com

Received 4 March 2019; Revised 25 May 2019; Accepted 28 May 2019; Published 13 June 2019

Academic Editor: Gilberto Sammartino

Copyright (C) 2019 Ana Stefany Meza-Siccha et al. This is an open access article distributed under the Creative Commons Attribution License, which permits unrestricted use, distribution, and reproduction in any medium, provided the original work is properly cited.

\begin{abstract}
Objective. To evaluate the in vitro adherence and viability of 3 bacterial species Streptococcus mutans (ATCC 25175), Streptococcus sanguinis (ATCC 10556), and Porphyromonas gingivalis (ATCC 33277) on the surfaces of dental implants of titanium, zirconium, and their respective fixing screws. Methods. Two analysis groups were formed: group 1 with 3 titanium pillars and group 2 with 3 zirconium pillars, each with their respective fixing screws. Each of these groups was included in tubes with bacterial cultures of Streptococcus mutans (ATCC 25175), Streptococcus sanguinis (ATCC 10556), and Porphyromonas gingivalis (ATCC 33277). These samples were incubated at $37^{\circ} \mathrm{C}$ under anaerobic conditions. Bacterial adherence was assessed by measurement of the change in colony-forming units (CFU), and bacterial viability was evaluated with the colorimetric test of 3-(4,5-dimethylthiazol-2)-2,5 diphenyl tetrazolium bromide (MTT). Results. The bacterial adhesion in the titanium abutments was higher for Streptococcus mutans $(190.90 \mathrm{CFU} / \mathrm{mL})$, and the viability was greater in Porphyromonas gingivalis $(73.22 \%)$. The zirconium abutment group showed the highest adherence with Streptococcus mutans $(331.82 \mathrm{CFU} / \mathrm{mL})$ and the highest bacterial viability with the $S$. sanguinis strain $(38.42 \%)$. The titanium fixation screws showed the highest adhesion with S. sanguinis (132.5 CFU/mL) compared to the zirconium fixation screws where $S$. mutans had the highest adhesion $(145.5 \mathrm{CFU} / \mathrm{mL})$. The bacterial viability of $S$. mutans was greater both in the titanium fixation screws and in the zirconium fixation screws $78.04 \%$ and $57.38 \%$, respectively. Conclusions. Our results indicate that there is in vitro bacterial adherence and viability in both titanium abutments and zirconium abutments and fixation screws for both. Streptococcus mutans is the microorganism that shows the greatest adherence to the surfaces of both titanium and zirconium and the fixing screws of the latter. On the contrary, bacterial viability is greater on the titanium abutments with $P$. gingivalis than on the zirconium abutments with $S$. sanguinis. With respect to the fixation screws, in both cases, the viability of $S$. mutans was greater with respect to the other bacteria. In general, the titanium abutments showed less adherence but greater bacterial viability.
\end{abstract}

\section{Introduction}

A biofilm is considered a bacterial functional community made up of one or more species of microorganisms attached to a solid surface. The pathogenesis of periodontal inflammation begins with the colonization of pathogenic bacteria in a susceptible host, although other environmental factors also play a role in the development of disease [1]. The accumulation of bacterial plaque is required for the development of periodontal inflammation and is also an essential 
step in other periodontal pathologies [2]. According to Socransky [3], specific bacteria have niche locations of colonization within the oral cavity, and their characteristics are subdivided into primary and secondary colonizers. We have included Streptococcus mutans and Streptococcus sanguinis in our study because the Streptococcus spp. are considered primary colonizers. We have also included Porphyromonas gingivalis, a secondary colonizer [3], because of its strong association with peri-implantation pathologies [4].

The conventional dental implant is a two-piece implant that consists of a root component known as the implant and the abutment. This procedure is considered the most successful management for the replacement of missing teeth [5]. When a disequilibrium between pathogenic and nonpathogenic bacteria in the oral microbiota occurs, there is a subsequent increase in adherence of bacteria and therefore an increase in the risk of periodontal infection, most commonly peri-implant mucositis and peri-implantitis [6].

Multiple factors are involved in the pathogenesis of periimplant disease, including systemic disease like diabetes [7], a previous history of tobacco [8], or periodontitis [9]. However, despite the multifactorial etiology of peri-implant infections, a common denominator lies in the fact that the dental implant must be colonized with specific bacteria before disease onset. Finding the bacterial adhesion and viability of different material abutments will aid in the etiologic understanding of the disease [10].

A previous meta-analysis showed that the prevalence of peri-implantitis was $9.83 \%$ and the prevalence of periimplant mucositis was 29.48\%. [11] Bacterial adherence on conventional dental implants is the primary cause for the development of peri-implanting mucositis and periimplantitis. The characteristics of the surface of the dental abutment will contribute to the adherence of microorganisms $[12,13]$.

The objective of this study is to evaluate the adherence and viability of Streptococcus mutans, Streptococcus sanguinis, and Porphyromonas gingivalis when exposed in vitro to the surface of zirconium and titanium abutments and fixing screws.

\section{Materials and Methods}

2.1. Samples. Our sample included 6 bacterial cultures with different strains of Streptococcus mutans (ATCC 25175), Streptococcus sanguinis (ATCC 10556), and Porphyromonas gingivalis (ATCC 33277) with abutments of two different materials, titanium, and zirconium.

The dental abutments of titanium and zirconium were acquired from Biohorizons ${ }^{\circledR}$, and the bacterial strain samples of Streptococcus mutans (ATCC 25175), Streptococcus sanguinis (ATCC 10556), and Porphyromonas gingivalis (ATCC 33277) were obtained from Gen Lab in Peru, a representative of MicroBiologics ${ }^{\circledR}$ (USA). The exclusion criteria in this study included abutments of titanium or zirconium with rugose surfaces, with irregular cuts or those not sealed correctly.

We proceeded to sterilize the materials for 15 minutes under UV light inside a laminar flow cabin type II.
2.2. Bacterial Culture. The bacterial samples of Streptococcus mutans, Streptococcus sanguinis, and Porphyromonas gingivalis were cultured independently in blood agar plates with supplemental $10 \%$ sterile bovine blood. The culture was carried out following the manufacturer's instructions. The plates containing the bacteria were incubated in an Anaerocult ${ }^{\circledR}$ and Anaerotest ${ }^{\circledR}$ controlled anaerobic chamber at $37^{\circ} \mathrm{C}$ for 10 days in the case of Porphyromonas gingivalis and for 3 days in the case of Streptococcus mutans and Streptococcus sanguinis.

\subsection{Cultures to Evaluate Adhesion and Bacterial Viability.} The titanium and zirconium abutments and their corresponding fixing screws were placed on a sterile Petri dish with 24 pits (Falcon Plastics, Oxnard, CA), and $1000 \mu \mathrm{L}$ of a bacterial suspension with a $0.5 \mathrm{McF}$ arland scale density was added to each pit. The samples were then incubated at $37^{\circ} \mathrm{C}$ for 72 hours under controlled anaerobic conditions. The bacterial adhesion and bacterial viability were evaluated once the incubation period was over.

The bacterial adhesion was evaluated by measuring colony-forming units (CFU). Serial dilutions were made in order to obtain the lower quantity of bacteria in the sample. Subsequently, a plate dissemination method was utilized, and a direct microscopic count of CFU was done for each sample $[14,15]$.

The bacterial viability was evaluated by determining the absorbance values measured by an ELISA reader (Bio-Rad) following colorimetric MTT tests based on the reduction of mitochondrial enzymes [16].

\section{Results}

3.1. Adherence and Bacterial Viability on the Surface of Titanium Abutments and Fixing Screws. The bacterial adherence was determined using CFU measured by direct microscopic count. The in vitro evaluation of titanium abutment showed the highest bacterial adherence (190.90 CFU/mL) with Streptococcus mutans followed by adherence values of 167.5 and $153.9 \mathrm{CFU} / \mathrm{mL}$ for S. sanguinis and $P$. gingivalis, respectively. In relation to the bacterial viability, $P$. gingivalis showed the highest value with $73.22 \%$ while $S$. mutans and $S$. sanguinis showed bacterial viability of $55.37 \%$ and $52.58 \%$, respectively.

The fixing screw had the highest bacterial adherence for S. sanguinis $(132.5 \mathrm{CFU} / \mathrm{mL})$ and the highest bacterial viability with $S$. mutans (78.04\%) (Figure 1).

3.2. Adherence and Bacterial Viability on the Surface of Zirconium Abutments and Fixation Screws. The in vitro evaluation of the zirconium abutment showed the highest bacterial adherence for $S$. mutans with $331.82 \mathrm{CFU} / \mathrm{mL}$ followed by $S$. sanguinis and $P$. gingivalis with values of $135 \mathrm{CFU} / \mathrm{mL}$ and $228.80 \mathrm{CFU} / \mathrm{mL}$, respectively. In relation to the bacterial viability, S. sanguinis had $38.42 \%$ followed by S. mutans with $29.82 \%$ and $P$. gingivalis with $28.26 \%$.

The results of the fixation screw showed a similar adherence to $S$. mutans $(145.45 \mathrm{CFU} / \mathrm{mL}), S$. sanguinis 


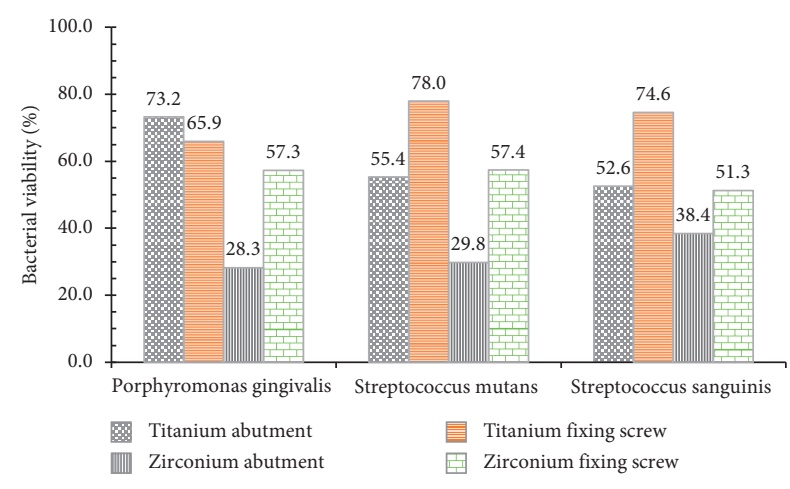

FIgUre 1: Bacterial viability of Streptococcus mutans (ATCC 25175), Streptococcus sanguinis (ATCC 10556), and Porphyromonas gingivalis (ATCC 33277) on the abutment surface and fixing screw of titanium and zirconium.

(142.5 CFU $/ \mathrm{mL})$, and $P$. gingivalis $(106.5 \mathrm{CFU} / \mathrm{mL})$. The values for bacterial viability also showed some similarities with S. mutans and S. sanguinis with values of $57.38 \%$ and $57.33 \%$, respectively. $P$. gingivalis had the lowest bacterial viability with $51.31 \%$ (Figure 2 ).

\section{Discussion}

The oral cavity has a particular bacterial population with the capacity to form biofilms, which allows it to coexist with the tissues that surround them. Oral bacteria are established and grow in situ because they achieve adhesion to the hard surface of the teeth and soft epithelial tissues [17-19]. These characteristics are of special importance in the current implantology because the implant constitutes a key element for an adequate and sustainable osseointegration in the process of restoring a tooth that was extracted due to caries, disruptive periodontal disease, or agenesis [20-23]. In this context, inflammatory diseases, including infections that affect the soft and hard tissues surrounding an implant, represent a challenge in the search for strategies for decontamination of implant surfaces and identification of the bacteria that can colonize these structures in order to maintain a healthy interface between connective tissue and implants [24, 25].

Our in vitro results show $S$. mutans as an important colonizer that adheres to the abutment surfaces of both titanium and zirconium. A similar result was described in a study performed in vivo with titanium alloy implants coated with titanium nitride (TiN) compared to uncoated titanium implants. After a 24-hour exposure to the oral microbiota, it was found that implants coated with TiN had a smaller amount of surface covered by bacteria from the oral cavity [26]. As for the zirconium abutments, previous studies show that zirconium oxide is a material with a low colonization potential, and even a lower bacterial adherence compared to titanium is described. These results are different from those described in our work where the titanium abutments showed less bacterial adherence compared to the zirconium abutments, but at the same time, greater bacterial viability is described $[27,28]$.
Other studies performed in vivo using real-time polymerase chain reaction or universal 16S PCR with RFLP obtained very similar results to ours, where it is noted that the surfaces of zirconium oxide and those of titanium alloys are similar in their tendency to adhesion and colonization of A. actinomycetemcomitans and P gingivalis, both periodontal bacteria that adhere to hard surfaces and soft tissues. However, they only assessed bacterial adherence and not viability $[29,30]$. In this context, it is important to emphasize that there is an influence on the bacterial adhesion and on the viability related to the mechanochemical properties of all the components of the implant on different types of surface [31].

On the contrary, there are few studies that describe or determine the bacterial viability on the surface of dental implants; in our work, the bacterial viability was different as far as the pathogen involved in a predominant way. $P$. gingivalis predominated in the titanium pillars and $S$. sanguinis predominated in the pillars of zirconium. In this regard, a study published in 2018 made use of fluorophores, and the processing of images by means of multiphoton microscopy for the analysis of bacterial viability in a heterogeneous population of microorganisms after 48 hours of growth determined that the bacterial viability was similar between the materials of test based on zirconium and titanium [32].

Finally, in the case of the fixation screw, very few studies describe the in vitro adhesion and bacterial viability in the titanium and zirconia fixation screws. According to Dibart et al. and do Nascimento et al., the leakage of bacteria between the abutment and the fixation screw occurs when it is necessary to adjust the screw. However, they recommend further studies to confirm whether the constant adjustment of the fixation screw can increase the incidence of periimplant disease; in this context, it is important to minimize the presence of bacteria in relation to the abutment-implant connection $[33,34]$. In this regard, one study compared the growth of bacterial colonies between anatase-coated titanium healing screws and uncoated titanium healing screws without establishing statistically significant differences in bacterial adhesion and biofilm formation [20,34]. Perhaps this result is due to the region of the screw evaluated. Scarano et al. evaluated the surface of supra-alveolar screws without finding differences in bacterial colonization between the control groups and the test sample with atanasa, and another is the result when they evaluated the surfaces of the intra-alveolar screws, where the healing screws covered by atanasa present a low colonization potential [35].

In conclusion, our results indicate that there is in vitro bacterial adherence and viability in both titanium and zirconium abutments and fixation screws for both. Streptococcus mutans is the microorganism that shows the greatest adherence to the surfaces of both titanium and zirconium and the fixing screws of the latter. On the contrary, bacterial viability is greater on the titanium abutments with $P$. gingivalis than on the zirconium abutments with $S$. sanguinis. With respect to the fixation screws, in both cases, the viability of $S$. mutans was greater with respect to the other 


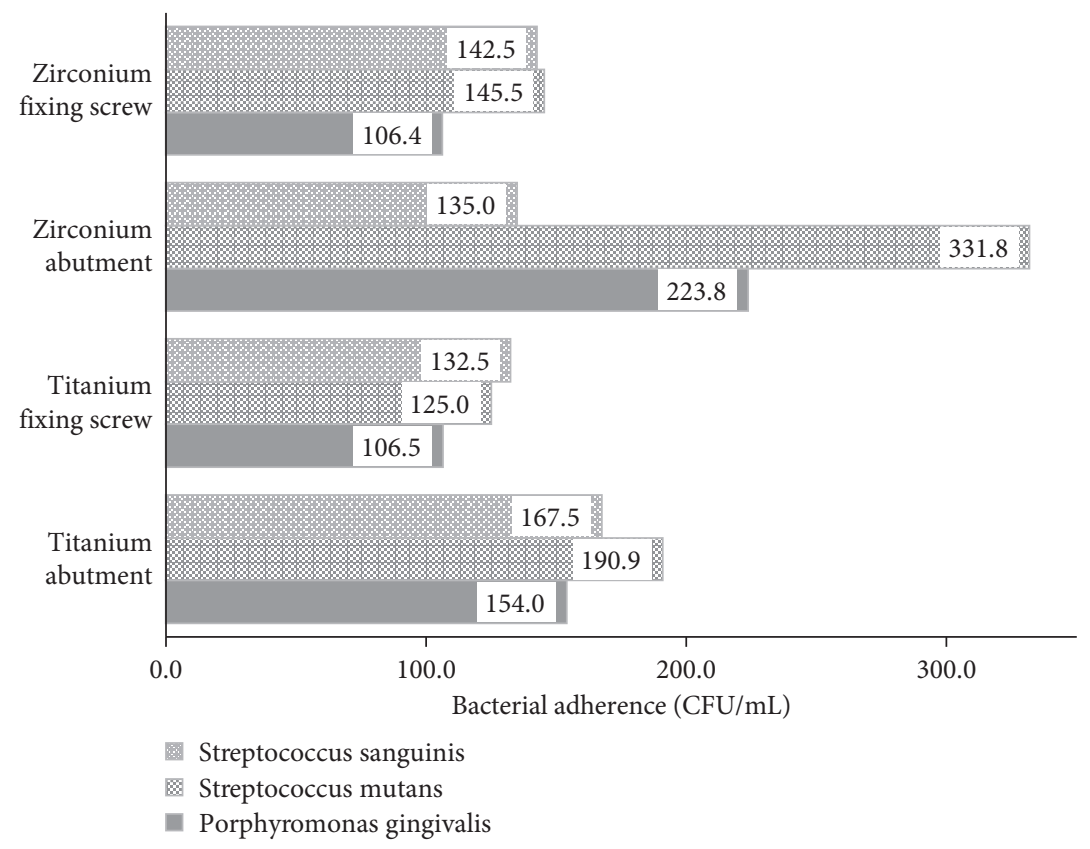

Figure 2: In vitro evaluation of bacterial adherence of Streptococcus mutans (ATCC 25175), Streptococcus sanguinis (ATCC 10556), and Porphyromonas gingivalis (ATCC 33277) on the surface of zirconium/titanium abutment dental implants and fixing screw (CFU = colonyforming units).

bacteria. In general, the titanium abutments showed less adherence but greater bacterial viability.

\section{Limitations}

One of the main limitations of the study was that the physical parameters of the zirconium and titanium surfaces were not evaluated, neither for pillars nor for screws. Furthermore, our results cannot be extrapolated to what could happen in living tissues since it was done in vitro. The sample size was also a limitation since with a larger sample number, we could perform statistical tests. However, we are focused on carrying out additional experiments, taking into consideration various parameters and carrying out experiments in vivo in the future.

\section{Data Availability}

The data used to support the findings of this study are available from the corresponding author upon request.

\section{Disclosure}

This manuscript is based on the thesis by author Ana Stefany Meza-Siccha available at https://repositorioacademico.upc. edu.pe/handle/10757/622856.

\section{Conflicts of Interest}

The authors declare no conflicts of interest.

\section{Acknowledgments}

This study was supported by the Incentives for Research of the Universidad Peruana de Ciencias Aplicadas (Grant no. UPC-COA-25-2017), Lima, Peru.

\section{References}

[1] F. Llambés, S. Arias, and R. Caffesse, "Relationship between diabetes and periodontal infection," World Journal of Diabetes, vol. 6, no. 7, pp. 927-935, 2015.

[2] T. Ammann, G. Belibasakis, and T. Thurnheer, "Impact of early colonizers on in vitro subgingival biofilm formation," PLoS One, vol. 12, no. 8, Article ID e83090, 2013.

[3] S. S. Socransky, "Microbiology of periodontal disease-present status and future considerations," Journal of Periodontology, vol. 48, no. 9, pp. 497-504, 1977.

[4] H. Nagashima, M. Shinoda, K. Honda, N. Kamio, and $\mathrm{M}$. Watanabe, "CXCR4 signaling in macrophages contributes to periodontal mechanical hypersensitivity in Porphyromons gingivalis-induced periodontitis in mice," Molecular Pain, vol. 13, pp. 1-8, 2017.

[5] I.-S. Yeo, H.-Y. Kim, K. S. Lim, and J.-S. Han, "Implant surface factors and bacterial adhesión: a review of the literature," International Journal of Artificial Organs, vol. 35, no. 10, pp. 762-772, 2012.

[6] M. Ko car, K. Seme, and N. Ihan, "Characterization of the normal bacterial flora in peri-implant sulci of partially and completely edentulous patients," International Journal of Oral \& Maxillofacial Implants, vol. 25, no. 4, pp. 690-698, 2010.

[7] G. Taylor and W. Borgnakke, "Periodontal disease: associations with diabetes, glycemic control and complications," Oral Diseases, vol. 14, no. 3, pp. 191-203, 2008.

[8] F. Sgolastra, A. Petrucci, M. Severino, R. Gatto, and A. Monaco, "Periodontitis, implant loss and peri-implantitis. A meta-analysis," Clinical Oral Implants Research, vol. 26, no. 4, pp. e8-e16, 2015.

[9] I. K. Karoussis, G. E. Salvi, L. J. A. Heitz-Mayfield, U. Bragger, C. H. F. Hammerle, and N. P. Lang, "Long-term implant prognosis in patients with and without a history of chronic periodontitis: a 10-year prospective cohort study of the ITIR 
dental implant system," Clinical Oral Implants Research, vol. 14, no. 3, pp. 329-339, 2003.

[10] I. Hauser, S. Stübinger, and J. Meyer, "Bactericidal effects of different laser systems on bacteria adhered to dental implant surfaces: an in vitro study compraring zirconia with titanium," Clinical Oral Implants Research, vol. 21, no. 3, pp. 277-283, 2010.

[11] C.-T. Lee, Y.-W. Huang, L. Zhu, and R. Weltman, "Prevalences of peri-implantitis and peri-implant mucositis: systematic review and meta-analysis," Journal of Dentistry, vol. 62, pp. 1-12, 2017.

[12] A. Han, J. K. H. Tsoi, F. P. Rodrigues, J. G. Leprince, and W. M. Palin, "Bacterial adhesion mechanisms on dental implant surfaces and the influencing factors," International Journal of Adhesion and Adhesives, vol. 69, no. 5, pp. 58-71, 2016.

[13] C. Do Nascimiento, M. Sucena, E. De Souza, N. Monesi, and V. Pedrazzi, "Microbiome of titanium and zirconia dental implants abutments," Dental Materials, vol. 32, no. 1, pp. 93-101, 2016.

[14] G. Tortora, R. Berdell, and C. Case, Introducción a la Microbiología 3ra Edición, Editorial Panamericana, Buenos Aires, Argentina, 2007.

[15] A. Camacho, M. Giles, A. Ortegón, B. Serrano, and O. Velázquez, Técnicas Para el Análisis Microbiológico de Alimentos, UNAM, Mexico City, México, 2nd edition, 2009.

[16] J. Meerloo, G. Kspers, and J. Cloos, "Cell sensitivity assays: the MTT assay,” Cancer Cell Culture, vol. 731, pp. 237-245, 2011.

[17] P. E. Kolenbrander, R. J. Palmer, S. Periasamy, and N. S. Jakubovics, "Oral multispecies biofilm development and the key role of cell-cell distance," Nature Reviews Microbiology, vol. 8, no. 7, pp. 471-480, 2010.

[18] S. Bernardi, G. Marzo, and M. Adelaide Continenza, "Dorsal lingual surface and halitosis: a morphological point of view," Acta Stomatologica Croatica, vol. 50, no. 2, pp. 151-157, 2016.

[19] M. S. Aparna and S. Yadav, "Biofilms: microbes and disease," Brazilian Journal of Infectious Diseases, vol. 12, no. 6, pp. 526-530, 2008.

[20] S. Bernardi, S. Bianchi, G. Botticelli et al., "Scanning electron microscopy and microbiological approaches for the evaluation of salivary microorganisms behaviour on anatase titanium surfaces: in vitro study," Morphologie, vol. 102, no. 336, pp. 1-6, 2018.

[21] A. Jokstad, "Oral implants-the future," Australian Dental Journal, vol. 53, no. 1, pp. S89-S93, 2008.

[22] G. Falisi, S. Bernardi, C. Rastelli et al., "“All on short” prosthetic-implant supported rehabilitations," Oral \& Implantology, vol. 10, no. 4, pp. 477-487 4, 2017.

[23] S. Bernardi, R. Gatto, M. Severino et al., "Short versus longer implants in mandibular alveolar ridge augmented using osteogenic distraction: one-year follow-up of a randomized split-mouth trial," Journal of Oral Implantology, vol. 44, no. 3, pp. 184-191, 2018.

[24] S. Bernardi, S. Bianchi, A. R. Tomei, M. A. Continenza, and G. Macchiarelli, "Microbiological and SEM-EDS evaluation of titanium surfaces exposed to periodontal gel: in vitro study," Materials (Basel), vol. 12, no. 9, 2019.

[25] S. J. Hoshaw, J. B. Brunki, and G. V. D. Cochran, "Mechanical loading of Branemark implants affects interfacial bone modeling and remodeling," International Journal of Oral \& Maxillofacial Implants, vol. 9, pp. 345-360, 1994.

[26] A. Scarano, M. Piattelli, G. Vrespa, S. Caputi, and A. Piattelli, "Bacterial adhesion on titanium nitride-coated and uncoated implants: an in vivo human study," Journal of Oral Implantology, vol. 29, no. 2, pp. 80-85, 2003.

[27] A. Scarano, M. Piattelli, S. Caputi, G. A. Favero, and A. Piattelli, "Bacterial adhesion on commercially pure titanium and zirconium oxide disks: an in vivo human study," Journal of Periodontology, vol. 75, no. 2, pp. 292-296, 2004.

[28] I. Sailer, A. Philipp, A. Zembic, B. E. Pjetursson, C. H. F. Hämmerle, and M. Zwahlen, "A systematic review of the performance of ceramic and metal implant abutments supporting fixed implant reconstructions," Clinical Oral Implants Research, vol. 20, pp. 4-31, 2009.

[29] U. Salihoglu, D. Boynuegri, D. Engin, A. N. Duman, P. Gokalp, and K. Balos, "Bacterial adhesion and colonization differences between zirconium oxide and titanium alloys: an in vivo human study," International Journal of Oral \& Maxillofacial Implants, vol. 26, no. 1, pp. 101-107, 2011.

[30] K. Yamane, Y. Ayukawa, T. Takeshita, A. Furuhashi, Y. Yamashita, and K. Koyano, "Bacterial adhesion affinities of various implant abutment materials," Clinical Oral Implants Research, vol. 24, no. 12, pp. 1310-1315, 2013.

[31] A. S. D. Al-Radha, D. Dymock, C. Younes, and D. O'Sullivan, "Surface properties of titanium and zirconia dental implant materials and their effect on bacterial adhesion," Journal of Dentistry, vol. 40, no. 2, pp. 146-153, 2012.

[32] T. S. O. Silva, A. R. Freitas, M. L. L. Pinheiro, C. do Nascimento, E. Watanabe, and R. F. Albuquerque, "Oral biofilm formation on different materials for dental implants," Journal of Visualized Experiments, no. 136, 2018.

[33] S. Dibart, M. Warbington, M. F. Su, and Z. Skobe, "In vitro evaluation of the implant-abutment bacterial seal: the locking taper system," International Journal of Oral \& Maxillofacial Implants, vol. 20, no. 5, pp. 732-737, 2005.

[34] C. do Nascimento, V. Pedrazzi, P. K. Miani, L. D. Moreira, and R. F. De Albuquerque Junior Jr., "Influence of repeated screw tightening on bacterial leakage along the implantabutment interface," Clinical Oral Implants Research, vol. 20, no. 12, pp. 1394-1397, 2009.

[35] A. Scarano, A. Piattelli, A. Polimeni, D. Di Iorio, and F. Carinci, "Bacterial adhesion on commercially pure titanium and anatase-coated titanium healing screws: an in vivo human study," Journal of Periodontology, vol. 81, no. 10, pp. 14661471, 2010. 


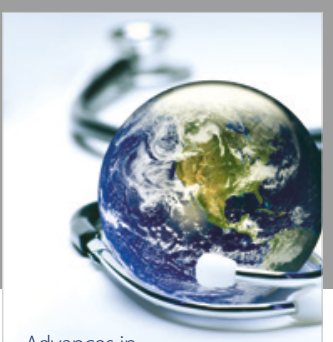

Advances in
Public Health

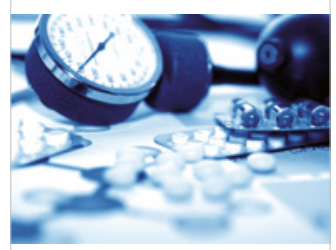

Case Reports in

Medicine

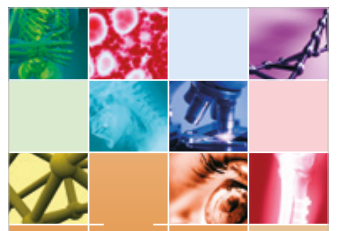

niernational Journal of

Biomaterials
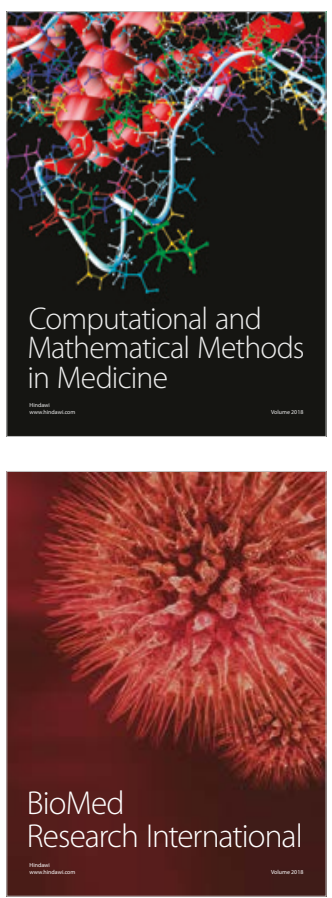

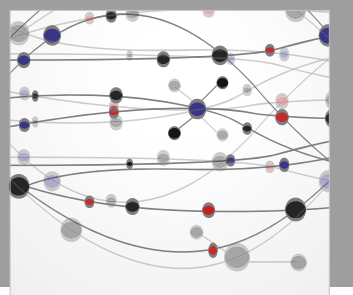

The Scientific World Journal Dentistry

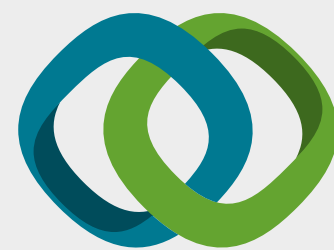

Hindawi

Submit your manuscripts at

www.hindawi.com
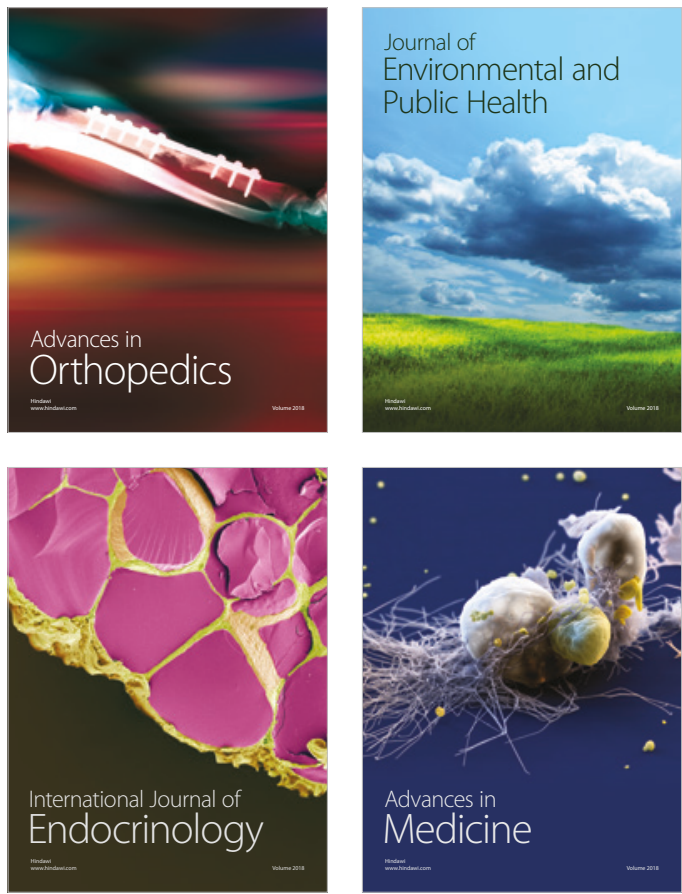
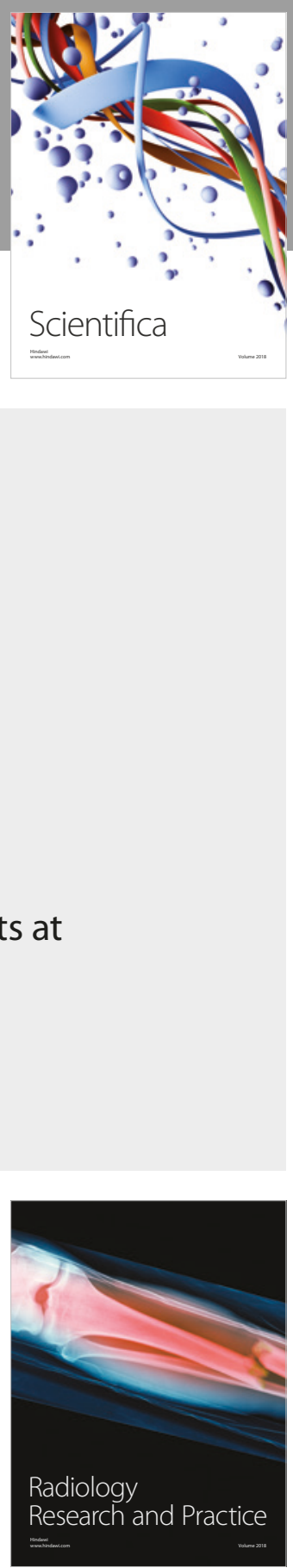

Scientifica

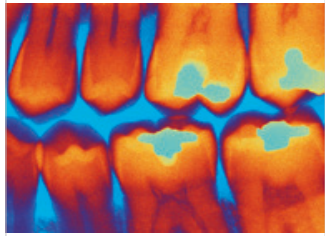

Case Reports in

Dentistry
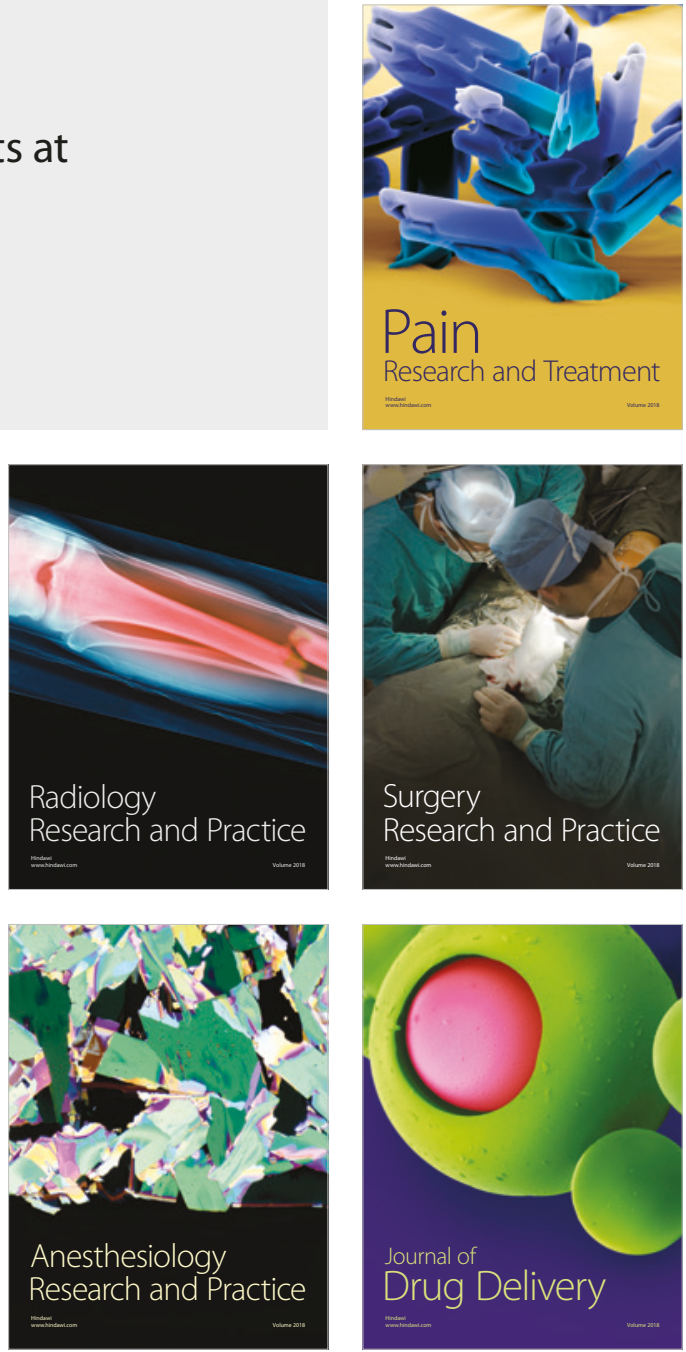